\title{
Translation of preprochymosin in vitro
}

\author{
Evidence for folding of prochymosin to the native conformation
}

\author{
Amina SHEIKH and Robert B. FREEDMAN \\ The Biological Laboratory, University of Kent, Canterbury, Kent CT2 7NJ, U.K.
}

\begin{abstract}
1. The cDNA coding for preprochymosin has been sub-cloned into the transcription/translation vector pGEM-3Z, the $\mathrm{T}_{7}$ promoter used to transcribe the gene and the product expressed in an 'in vitro' cell-free system comprising rabbit reticulocyte lysate and dog pancreatic microsomes. 2. Translations in various conditions, and analyses of the translation product in reducing and non-reducing conditions, indicate that oxidizing translation conditions and the cleavage of the $N$-terminal 'pre-' sequence are essential for generation of a disulphide-bonded translation product. 3 . The disulphidebonded translation product was resistant to proteinases, as expected for a translation product segregated within microsomal vesicles; in the presence of detergent to solubilize the membranes, the product was not readily susceptible to proteolysis, and was converted to a proteinase-resistant core fragment. 4. Segregated prochymosin, synthesized in reducing conditions, was completely degraded by proteinases under similar conditions. 5 . Proteinase treatment of purified recombinant prochymosin gave rise to a proteinase-resistant fragment of similar $M_{\mathrm{r}}$, suggesting that the disulphidebonded product of translation in vitro was correctly folded. 6. The translocated, disulphide-bonded and folded prochymosin could be converted into pseudochymosin at $\mathrm{pH} 2.0$, and addition of chymosin to the activation mixture resulted in increased pseudochymosin production.
\end{abstract}

\section{INTRODUCTION}

The process of protein folding has been studied for many years by application of sophisticated physical techniques to monitor the re-folding of denatured unfolded mature proteins (Jaenicke, 1987). With increasing interest in the cellular context of protein folding at biosynthesis, methods are needed to study protein folding co-translationally. The cloning of cDNA sequences into transcription/translation vectors permits the translation in vitro of proteins of choice, but methods for characterizing the translation products in vitro have been limited. The conventional determination of $M_{\mathrm{r}}$ by reducing SDS/PAGE sacrifices all conformational information. We have sought to use a range of translation conditions, post-translational product treatments and analytical electrophoretic systems to study the conformations of polypeptides translated in vitro. Co-translational formation of disulphide bonds was observed previously in work on prolactin and wheat storage proteins (Kaderbhai \& Austen, 1985; Bulleid \& Freedman, $1988 a, b)$. Here we have sought wider conformational information by studying the co-translation folding of bovine prochymosin.

The aspartyl proteinase chymosin has the physiological function of clotting milk in the fourth stomach of the unweaned calf (Foltmann, 1970). The mRNA codes for the precursor polypeptide preprochymosin, consisting of 381 amino acids $\left(M_{\mathrm{r}}\right.$ approx. 42000). The product of biosynthesis, or of 'in vitro' translation in the presence of microsomal membranes, is the zymogen prochymosin $\left(M_{\mathrm{r}} \sim 40000\right)$, which is smaller by the loss of a 16-amino-acid signal peptide (Foltmann et al., 1977; Harris et al., 1982; Moir et al., 1982). The inactive zymogen is converted into active chymosin $\left(M_{\mathrm{r}} 35000\right)$ through the loss of a 42-amino-acid sequence at the $N$-terminus (Pedersen \& Foltmann, 1975). The cleavage of the pro sequence is the final step in an autocatalytic process which is activated under acid conditions. An intermediate cleavage product, termed pseudochymosin, involving the removal of a 27-amino-acid fragment from the pro sequence, is also known (Pedersen et al., 1979).
Calf preprochymosin cDNA has been cloned and sequenced (Harris et al., 1982; Moir et al., 1982). Prochymosin contains six cysteine residues which form three intra-molecular disulphide bonds. The tertiary structure of the protein has been defined on the basis of X-ray studies and sequence homology with other aspartic proteinases (Jenkins et al., 1977; Foltmann \& Pedersen, 1977).

This paper presents data available through sub-cloning of preprochymosin cDNA (pCT82; Mellor et al., 1983) into a plasmid vector, pGEM-3Z, which allows the transcription and translation in vitro of the full-length gene product. The translation system used employs a rabbit reticulocyte lysate and dog pancreatic microsomes in the absence of added reductant and is designed to detect co-translational translocation and disulphide bond formation of proteins (Bulleid \& Freedman, 1988a). Translation products were examined in an SDS/PAGE system both in reducing conditions and in conditions where the existing disulphide bonds are preserved. Such a system can distinguish between disulphide-bonded proteins, which are more compact and exhibit greater electrophoretic mobility, and proteins that have had their disulphide bonds reduced and are therefore unfolded; the latter have retarded mobility (Goldenberg \& Creighton, 1984). We have also explored the sensitivity of translation products to proteolysis and their capability for conversion to chymosin. A preliminary account of some of this work has been published (Bulleid et al., 1989).

\section{MATERIALS AND METHODS}

\section{Materials}

The preprochymosin gene was kindly provided by Dr. T. J. R. Harris (Celltech Group Ltd., Slough, Berks., U.K.) (Mellor et al., 1983). The Escherichia coli strain N2384 (F' dam13:: Tn9, recF143 thr-1, thi-1, leuB6, ProA2, ara-114, lacY1, galk2, xyl-5, mtl-1, tsx-33, supE44, rspL31) was generously supplied by Dr. R. G. Lloyd (Nottingham University, Nottingham, U.K.). Restriction enzymes $B c l 1$ and $B a m H 1, T_{4}$ DNA ligase, T, RNA

Abbreviations used: DTT, dithiothreitol; PMSF, phenylmethanesulphonyl fluoride; 7-mGpppG, 7-methylguanosylguanosine triphosphate.

Vol. 272 
polymerase, RNasin (RNAase inhibitor), ATP, CTP, UTP and GTP, and 7-methylguanosylguanosine triphosphate (7mGpppG) were purchased from Boehringer Mannheim. L$\left.{ }^{[35} \mathrm{S}\right]$ Methionine and Amplify were purchased from Amersham. The transcription/translation vector pGEM-3Z was purchased from Promega.

Dr. B. M. Austen (Department of Surgery, St. George's Hospital Medical School, London, U.K.) kindly provided dog pancreatic microsomal membranes (Austen et al., 1984). Recombinant prochymosin was supplied by Celltech (Dr. S. Angal). Chymosin (rennin), pepsinogen, proteinase K, trypsin, chymotrypsin and thermolysin were bought from Sigma. Chymosin and recombinant prochymosin were labelled with $\left[{ }^{14} \mathrm{C}\right]$ formaldehyde by reductive alkylation (Dottavio-Martin \& Ravel, 1978).

\section{Sub-cloning of the preprochymosin gene into pGEM-3Z}

The gene coding for preprochymosin (1146 bp) was provided in the plasmid pCT82 (Mellor et al., 1983), a derivative of pAT153 (Emtage et al., 1983). The entire gene was flanked by $B c l 1$ restriction endonuclease sites. The plasmid pCT82 was amplified in $E$. coli strain N2384, which lacks the dam methylase enzyme ( $B c l 1$ is inhibited by methylated DNA). pCT82 DNA was digested with $B c l l$ and the $1146 \mathrm{bp}$ fragment was isolated. pGEM-3Z was digested with $B a m \mathrm{H} 1$, which generates cohesive ends compatible with $B c l$. The $5^{\prime}$ end of the linearized pGEM$3 Z$ DNA was treated with calf intestine phosphatase in order to prevent self-ligation. The $B c l 1$ fragment and the linearized vector DNA were electroeluted from agarose and purified. They were then ligated together, maintaining a vector-to-insert ratio of $3: 1$. Transformation of $E$. coli strain $\mathrm{F}^{\prime} 11 \mathrm{rec} \mathrm{A}$ [A(lac pro), thi, rifA, strA, recA, $F^{\prime}$ traD36, proAB, lacl $\left.{ }^{q}, Z \Delta M 15\right]$ was carried out with the ligated DNA. Cells were made competent by $\mathrm{RbCl} / \mathrm{CaCl}_{2}$ treatment (Maniatis et al., 1982). Plasmid DNA from white colonies was screened by Pst 1 digestion. The insert DNA contains one Pstl restriction site and pGEM contains another. Recombinant plasmids produce a $1029 \mathrm{bp}$ fragment, with the gene orientated so that the $T_{7}$ promoter could be used to transcribe the gene. The recombinant plasmid was named pUKC1020. The coding sequence up to base 250 was confirmed by sequence analysis. Plasmid DNA from this clone was amplified in $E$. coli strain $\mathrm{F}^{\prime} 11$ and purified as described in Maniatis $e t$ al. (1982).

\section{Transcription of pUKC1020 in vitro}

A method developed by Krieg \& Melton (1984) was used. The plasmid pUKC1020 was linearized with $A c c 1$ and $2 \mu \mathrm{g}$ of the DNA was used per $100 \mu \mathrm{l}$ of the transcription mix, consisting of: $40 \mathrm{~mm}$-Tris/HCl, $\mathrm{pH} \mathrm{7.5,} 6 \mathrm{~mm}-\mathrm{MgCl}_{2}, 2 \mathrm{~mm}$-spermidine, $10 \mathrm{~mm}-\mathrm{NaCl}, 10 \mathrm{~mm}$-dithiothreitol (DTT), $0.5 \mathrm{~mm}$ each of ATP, CTP and UTP and $0.3 \mathrm{~mm}-$ GTP. In addition, a $5^{\prime}$ cap (7$\mathrm{mGpppG}$ ) at $0.25 \mathrm{mM}, 75$ units of RNasin ribonuclease inhibitor and 50 units of phage $T_{7}$ RNA polymerase were present. The total volume of $100 \mu \mathrm{l}$ was made up with DEPC (diethylpyrocarbonate)-treated water and the reaction incubated at $37^{\circ} \mathrm{C}$ for $1 \mathrm{~h}$. At the end of the incubation period, the reaction mix was extracted once with phenol and twice with chloroform/isoamyl alcohol $(24: 1, \mathrm{v} / \mathrm{v})$. The RNA was precipitated at $-20^{\circ} \mathrm{C}$ in the presence of $2.5 \mathrm{M}$-ammonium acetate and $2.5 \mathrm{vol}$. of ethanol. After a period of $16 \mathrm{~h}$ the RNA was pelleted, washed with $75 \%$ (v/v) ethanol and dessicated. The pellet was resuspended in $20 \mu \mathrm{l}$ of DEPC-treated water and stored at $-70^{\circ} \mathrm{C}$. A small sample of the RNA was analysed in a $0.8 \%$ agarose gel.

\section{Translation of pUKC1020 in vitro}

The reticulocyte lysate system of Pelham \& Jackson (1976) was used. This system is pre-treated with micrococcal nuclease, making it dependent on exogenously added mRNA, in our case the preprochymosin RNA. Canine pancreatic microsomal membranes were prepared as described by Bulleid \& Freedman $(1988 a)$. The redox conditions of the translation were varied in order to control the ability of the translation product to form disulphide bonds. In most cases DTT was not added to the lysates (Bulleid \& Freedman, 1988a). In some cases, where the redox state of the protein was not relevant, DTT $(2 \mathrm{~mm})$ was present.

The lysate was optimized with $1 \mathrm{~mm}$ mixed amino acids minus methionine, $50 \mathrm{~mm}$-potassium acetate, $0.75 \mathrm{~mm}$-magnesium acetate, $25 \mathrm{~mm}$-phosphocreatine, creatine kinase $(25 \mu \mathrm{g} / \mathrm{ml}), 1 \mathrm{~mm}-$ ATP, $0.2 \mathrm{~mm}$-GTP and $0.5 \mathrm{~mm}$-glucose 6-phosphate. Typically translation mixes contained in a final volume of $20 \mu \mathrm{l}: 16 \mu \mathrm{l}$ of reticulocyte lysate, $1 \mu \mathrm{l}$ of transcribed RNA, $15 \mu \mathrm{Ci}$ of $\mathrm{L}$ $\left[{ }^{35} \mathrm{~S}\right]$ methionine, $1 \mu \mathrm{l}$ of dog pancreatic microsomal membranes $(0.85 \mathrm{mg} / \mathrm{ml})$ and $1 \mu \mathrm{l}$ of sterile water. Translation mixes were incubated for $60 \mathrm{~min}$ at $30^{\circ} \mathrm{C}$ and processed for SDS/PAGE analysis.

\section{Post-translational proteolysis}

Proteolysis was conducted in the presence or absence of Triton $\mathrm{X}-1 \mathrm{C0}(1 \%, \mathrm{v} / \mathrm{v})$ in each case. Proteinase $\mathrm{K}$ treatment of samples was carried out post-translationally at a concentration of $200 \mu \mathrm{g} / \mathrm{ml}$ for $25 \mathrm{~min}$ on ice and terminated by adding phenylmethanesulphonyl fluoride (PMSF, $2 \mathrm{mg} / \mathrm{ml}$ ) and incubating for a further $5 \mathrm{~min}$. Chymotrypsin and trypsin were added together at a concentration of $100 \mu \mathrm{g} / \mathrm{ml}$ each in the presence of $8 \mathrm{mM}-\mathrm{CaCl}_{2}$, and the incubation was carried out for $1 \mathrm{~h}$ on ice; the reaction was stopped with aprotinin (5500 kallikrein-inhibitory units $/ \mathrm{ml}$ ). When trypsin alone was used, it was added to a concentration of $100 \mu \mathrm{g} / \mathrm{ml}$ in the presence of $8 \mathrm{mM}-\mathrm{CaCl}_{2}$ and incubated with the sample for $30 \mathrm{~min}$ on ice. The reaction was stopped with PMSF $(5.0 \mathrm{~mm})$, with a further incubation of $10 \mathrm{~min}$. Proteolysis by thermolysin $(200 \mu \mathrm{g} / \mathrm{ml})$ was carried out in the presence of $5 \mathrm{mM}-\mathrm{CaCl}_{2}$ and incubated with the sample for $4 \mathrm{~h}$ at $37^{\circ} \mathrm{C}$. The reaction was stopped with EDTA $(2 \mathrm{mg} / \mathrm{ml})$. Sample buffer was added prior to SDS/PAGE analysis.

\section{SDS/polyacrylamide-gel electrophoresis}

Samples were processed under either reducing or non-reducing conditions. For reducing conditions, 5 vol. of sample buffer (0.02 M-Tris/HCl pH 8.0, 2 mM-EDTA, 6\% (w/v) SDS, $20 \%$ sucrose and $0.003 \%$ Bromophenol Blue) were added, followed by DTT $(0.5 \mathrm{M}$, to give a final concentration of $50 \mathrm{~mm})$ and the mixture was boiled for $4 \mathrm{~min}$. On cooling, iodoacetamide $(100 \mathrm{~mm})$ was added and the samples were incubated at $22^{\circ} \mathrm{C}$ for $45 \mathrm{~min}$.

For non-reducing conditions, samples were iodoacetamide (100 mM)-treated for $10 \mathrm{~min}$ on ice, followed by the addition of 5 vol. of sample buffer and boiling for $4 \mathrm{~min}$.

SDS/PAGE was conducted by the method of Laemmli (1970).

\section{Acid activation}

After translation in vitro of prochymosin in the presence of microsomes, $10 \mu \mathrm{l}$ samples were removed and their $\mathrm{pH}$ lowered. Either $300 \mu \mathrm{l}$ of $0.01 \mathrm{M}-\mathrm{HCl}$ or $150 \mu \mathrm{l}$ of $\mathrm{pH} 4.7$ buffer $(0.1 \mathrm{M}$ sodium acetate/acetic acid) was added and the drop in $\mathrm{pH}$ monitored by indicator paper. After a $1 \mathrm{~h}$ incubation on ice, the $\mathrm{pH}$ was raised to $\mathrm{pH} 6.3$ by adding an equal volume of stop buffer (0.1 M-potassium sodium phosphate). Dialysis of the reaction mixes was conducted against water, at $4^{\circ} \mathrm{C}$ for $16 \mathrm{~h}$, followed by freeze-drying. The resulting material was resuspended in $10 \mu \mathrm{l}$ of water and processed for SDS/PAGE analysis as before. 


\section{RESULTS}

The cDNA clone for preprochymosin (1146 bp) was subcloned from pCT82 into the transcription/translation vector pGEM-3Z to generate the plasmid pUKC1020 (Fig. 1). After linearizing the plasmid with $A c c 1$, the gene was transcribed by $\mathrm{T}_{7}$ RNA polymerase. Translation of the mRNA was carried out in a rabbit reticulocyte lysate in the presence or absence of dog pancreatic microsomal vesicles. Since our interest was to observe co-translational folding and disulphide bond formation, translation was carried out in the absence of added reductant, unless otherwise stated. Products were analysed by SDS/PAGE in either reducing or non-reducing conditions. The formation of disulphide bonds during translation could be monitored by a difference in the mobility of translation products when analysed reduced or non-reduced, a disulphide-bonded translation product being more compact and hence migrating faster when analysed under non-reducing SDS/PAGE (Goldenberg \& Creighton, 1984; Bulleid \& Freedman, 1988a,b).

Experiments to characterize the preprochymosin translation product are shown in Fig. 2. When translation was carried out in the absence of added microsomes, a single major product of $M_{\mathrm{r}} 42000$, corresponding to preprochymosin, was observed (lanes 3 and 4); there was no difference in mobility of the preprochymosin when it was analysed in reducing (lane 3) or non-reducing (lane 4) conditions, implying that no disulphide bond formation occurred during translation, despite the nonreducing conditions. By contrast, when translation was carried out in the presence of dog pancreas microsomes (lanes 1 and 2) there was a marked increase in mobility of the product when analysed in non-reducing (lane 2) compared with reducing (lane 1) conditions. Furthermore, comparison of the products analysed in reducing conditions from translations in the presence and absence of microsomes (lane 1, cf. lane 3) indicates a small decrease in $M_{\mathrm{r}}$ in the presence of microsomes, corresponding to

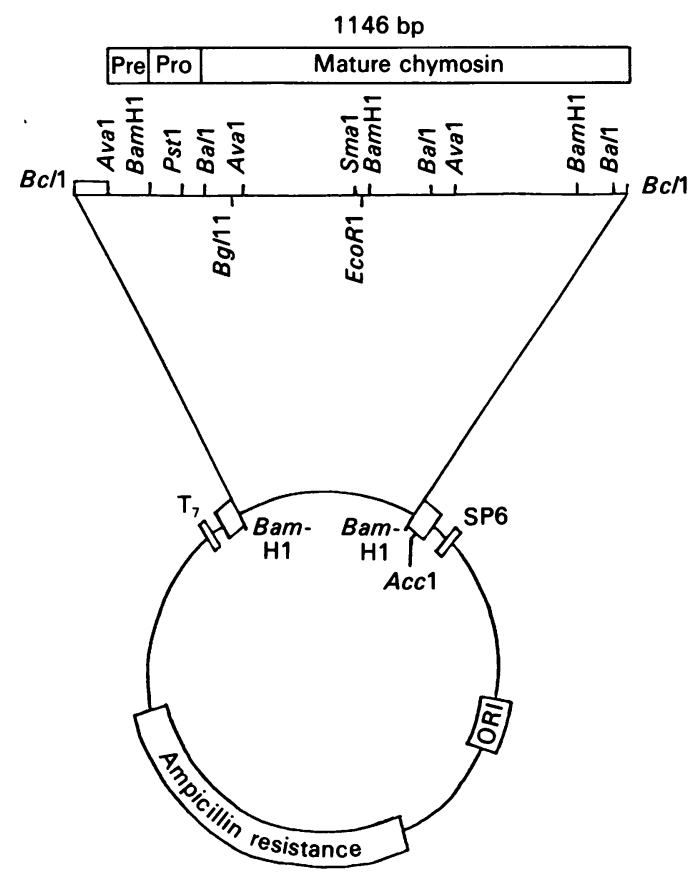

Fig. 1. Construct of pUKC1020

The cDNA clone for preprochymosin was sub-cloned into the Bam HI site of pGEM-3Z. The gene can be transcribed using the $T_{7}$ promoter.

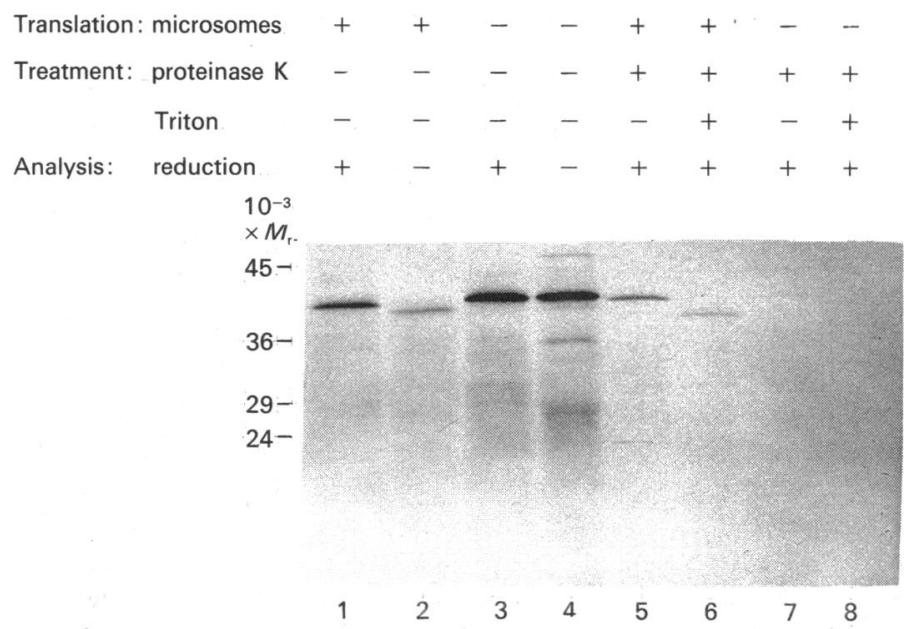

Fig. 2. Analysis of the products of translation in vitro of preprochymosin mRNA

RNA coding for preprochymosin was transcribed in vitro and translated in vitro in a rabbit reticulocyte lysate without added DTT, in the presence and absence of dog pancreas microsomes. Translation products were subjected to various post-translational treatments and were separated by SDS/PAGE on a $15 \%(\mathrm{w} / \mathrm{v})$ polyacrylamide gel (see the Materials and methods section for full details). Lanes 1, 2,5 and 6 show products of translation in the presence of microsomes; lanes 3, 4, 7 and 8 show products of translation in the absence of microsomes. Products of translation were separated under reducing conditions (lanes 1,3 and 5-8) or under nonreducing conditions (lanes 2 and 4). Products of translation were treated with proteinase $\mathrm{K}$ in the absence (lanes 5 and 7) or presence (lanes 6 and 8$)$ of $1 \%(\mathrm{v} / \mathrm{v})$ Triton X-100.

cleavage of the pre-sequence. Hence the translation product obtained in the presence of microsomes is processed and disulphide-bonded. Post-translational treatment of the preprochymosin obtained by translation in the absence of microsomes with proteinase $\mathrm{K}$, in both the absence and the presence of detergent, led to its complete degradation (lanes 7 and 8). Post-translational treatment with proteinase $K$ of the prochymosin obtained by translation in the presence of microsomes showed that it was protected from degradation (lane 5), consistent with its segregation within the microsomal vesicles. Interestingly, however, when this product was treated with proteinase $K$ in the presence of detergent (lane 6), it was not fully degraded, but cleaved to a proteinase $\mathrm{K}$-resistant fragment. The contrast with the result in lane 8 implies that the processed and disulphide-bonded prochymosin, after translocation into the microsomal vesicle, folds into a proteinase-resistant conformation.

To check that this apparent folding of the oxidized processed translation product was not an artefact arising from an unpredictable specificity of proteinase $\mathrm{K}$ action, products of translation in oxidizing conditions were also tested for susceptibility to a combination of trypsin and chymotrypsin (Fig. 3), and analysed in reducing conditions. Product translated in the absence of microsomal membranes was completely degraded by proteolysis in the absence (lane 1) or presence (lane 3) of detergent. Products obtained by translation in the presence of microsomes were degraded to a $38000-M_{\mathrm{r}}$ resistant fragment by the proteinase treatment in the presence of Triton (lane 4); proteinase treatment of this product in the absence of Triton generated some 38000 $M_{\mathrm{r}}$ resistant fragment, but some full-length $41000-M_{\mathrm{r}}$ prochymosin was also observed, consistent with there being some protection by the microsomal membrane. The marked 


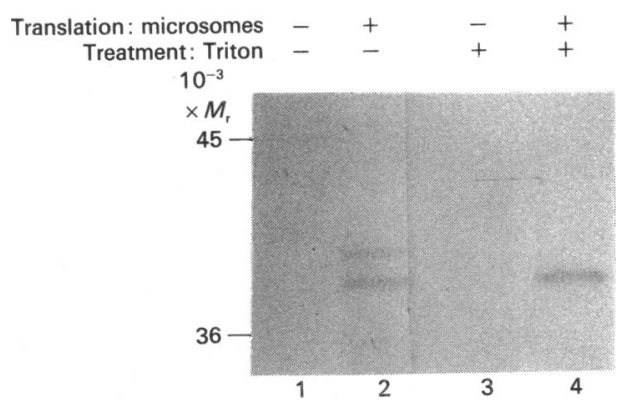

Fig. 3. Post-translational treatment of translation products with chymotrypsin and trypsin

Translation products synthesized in a non-reducing lysate were separated on a reducing $15 \%(\mathrm{w} / \mathrm{v})$ polyacrylamide gel. Lanes 1 and 3 show products translated in the absence of microsomes; lanes 2 and 4 show products translated in the presence of microsomes. Lanes 3 and 4 show products treated in the presence of $1 \%(\mathrm{v} / \mathrm{v})$ Triton X-100.

resistance of the oxidized prochymosin translation product to further degradation by this proteinase cocktail, in addition to its resistance to proteinase $K$, strongly suggests that the product is co-translationally folded into a proteinase-resistant conformation.

To test the requirements for this co-translational folding, we compared translation products generated under reducing and non-reducing conditions (Fig. 4). Product obtained by translation in reducing conditions and in the presence of microsomes (lane 1) was partially protected from proteinase digestion (lane 2), but was fully degraded by proteinase treatment in the presence of detergent to lyse the microsomal membranes (lane 3 ). By contrast, the product obtained by translation in the absence of added DTT was resistant to complete proteinase digestion in the presence of detergent, giving rise to a proteinase $\mathrm{K}$-resistant degradation product, as before (lane 4). It appears, therefore, that both processing and disulphide bond formation in the translation product are necessary to enable it to fold into a proteinase $\mathrm{K}$ resistant conformation.

In order to examine whether the co-translationally folded product observed in the above experiments resembled native prochymosin, authentic bovine prochymosin was subjected to proteinase treatment. Native unreduced calf prochymosin treated with proteinase $\mathrm{K}$ in the absence or presence of Triton gave rise to alternative high- $M_{\mathrm{r}}$ proteinase-resistant products of $M_{\mathrm{r}} 40000$

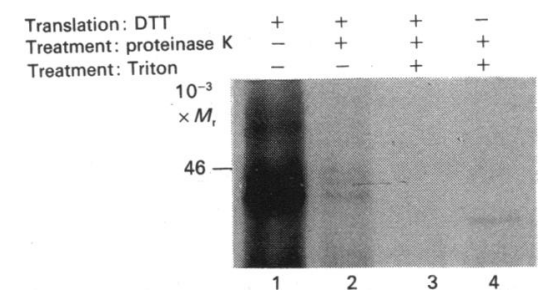

Fig. 4. Proteinase-resistance of products translated in reducing and nonreducing conditions

Translation was conducted in the presence of microsomal membranes using lysates with $(2 \mathrm{mM})$ and without added DTT, SDS/PAGE separation was on a reducing $12.5 \%$ (w/v) polyacrylamide gel. Lanes $1-3$, product translated in lysate plus DTT; lane 4, product translated in lysate minus DTT. Lanes 2-4 show proteinase $K$-treated prochymosin; in lanes 3 and 4, Triton $X-$ 100 was present during proteolysis.

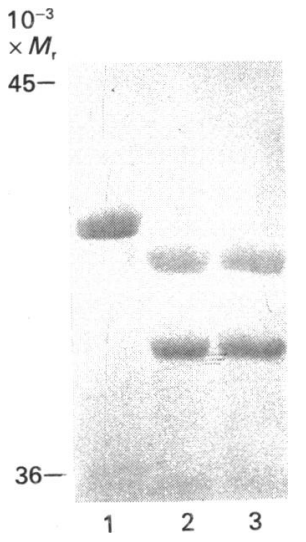

Fig. 5. Proteinase $K$ treatment of authentic prochymosin

Authentic prochymosin was subjected to treatment with proteinase $\mathbf{K}$ in conditions similar to those for the translated prochymosin. Proteins were separated on a reducing $11 \%(\mathrm{w} / \mathrm{v})$ polyacrylamide gel. Lane 1, untreated; lane 2, proteinase K-treated; lane 3, proteinase $\mathbf{K}$ and Triton-treated.

and $M_{\mathrm{r}} 38000$ (Fig. 5, lanes 2 and 3 cf. lane 1); a similar result was observed on treatment of the related zymogen, porcine pepsinogen (results not shown).

As a stringent test of whether prochymosin produced by translation in vitro in non-reducing conditions and in the presence of microsomes was folded into the native conformation, its ability to be activated to chymosin in acid conditions was examined. Acid activation of the 'in vitro' translated product was carried out at pH 2.0 and $\mathrm{pH} 4.7$. SDS/PAGE analysis of activated material revealed that, in the presence of microsomes at pH 2.0, prochymosin was converted into a product with the
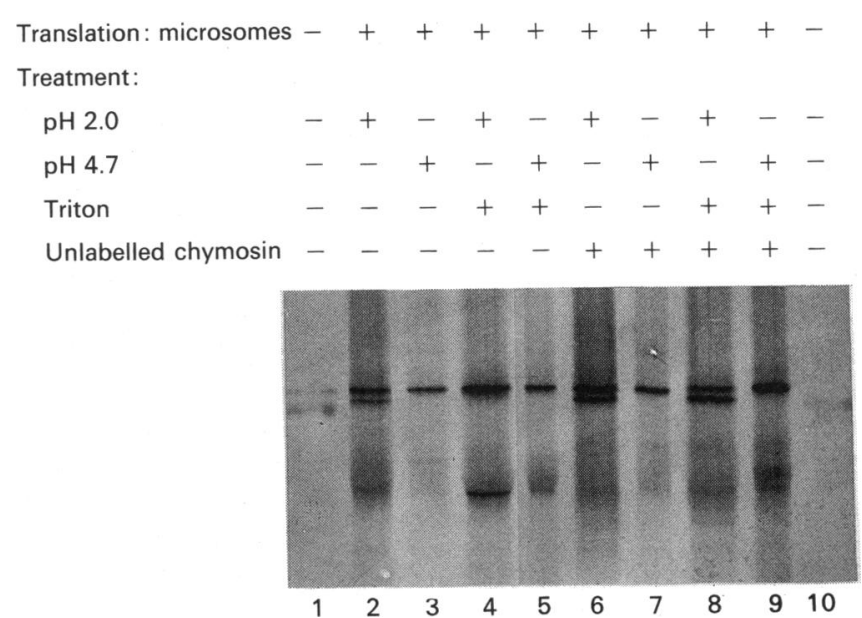

Fig. 6. Acid activation of prochymosin translated in vitro in the presence of dog pancreas microsomes

Translated prochymosin synthesized in the presence of microsomes in a non-reducing lysate was activated by lowering the $\mathrm{pH}$ to 2.0 and 4.7. The reactions were stopped by raising the $\mathrm{pH}$ to 6.3 . Dialysis of the activated material was carried out against water followed by a freeze-drying cycle. Activated material was separated on a nonreducing $12.5 \%(\mathrm{w} / \mathrm{v})$ polyacrylamide gel. Lanes 1 and 10 , controls, $\left(\left[{ }^{14} \mathrm{C}\right]\right.$ prochymosin and $\left[{ }^{14} \mathrm{C}\right]$ chymosin respectively). Lanes $2,4,6$ and 8 show pH 2.0-activated material; lanes 3, 5, 7 and 9 show pH 4.7-activated material. In lanes $4,5,8$ and 9 material was activated in the presence of $1 \%(v / v)$ Triton X-100; in lanes 6, 7, 8 and 9 activation was conducted in the presence of unlabelled chymosin. 
mobility of pseudochymosin (Fig. 6, lane 2; compare with the mobilities of standard prochymosin and chymosin, lanes 1 and 10), but no such conversion took place at pH 4.7 (lane 3). In the presence of Triton, production of pseudochymosin at $\mathrm{pH} 2.0$ was inhibited (lane 4). When unlabelled chymosin was added to the activation mixtures, proportionally more prochymosin could be activated to pseudochymosin at $\mathrm{pH} 2.0$ in both the presence and the absence of Triton (lanes 6 and 8, cf. lane 2). Comparable acid treatment of purified recombinant prochymosin indicated complete conversion to chymosin at $\mathrm{pH} 2.0$, and generation of a mixture of prochymosin, pseudochymosin and chymosin at pH 4.7 (results not shown); the presence of Triton slightly inhibited these conversions.

\section{DISCUSSION}

Studies that simulate cellular processes involved in the folding of proteins have lagged behind those involving the use of physical and chemical techniques to renature reduced and denatured proteins. In the past, interest in prochymosin has centred on its enzymology and its commercial value in the cheese manufacturing process (Foltmann, 1981). Recombinant prochymosin has been expressed in E. coli (Nishimori et al., 1982; Emtage et al., 1983) and the resulting inclusion bodies have been recovered, solubilized, denatured and re-folded to yield native material (Marston et al., 1984; Kawaguchi et al., 1984; Sugrue et al., 1988). However, this is the first instance where preprochymosin has been expressed and characterized in a cell-free translation system with the aim of using it as a model protein to study protein folding in vitro. This should help to achieve a better understanding of the process in vivo.

Conventional 'in vitro' translation systems include thiol reductants and are therefore not suitable for studying folding and disulphide bond formation. However, an 'in vitro' system incorporating a nuclease-treated rabbit reticulocyte lysate with no added reductant is efficient, in the presence of dog pancreas microsomes, in translating a defined exogenously added mRNA and co-translationally translocating the product into microsomes, with the removal of the signal peptide to produce the mature protein. Combined with an electrophoresis system that allows non-reduced samples to be analysed, such a system becomes extremely useful for studying correct protein folding (Bulleid \& Freedman, 1988a, $b$ ).

It has been possible to sub-clone the preprochymosin gene into a transcription/translation vector and synthesize the corresponding mRNA in vitro using a viral RNA polymerase. Translation of the transcript in our cell-free system has resulted in a product of $M_{\mathrm{r}}$ equivalent to that of the precursor preprochymosin. The presence of dog pancreas microsomal membranes in the system allowed co-translation translocation and signal peptide cleavage of the polypeptide. The resulting species had the $M_{\mathrm{r}}$ of the zymogen prochymosin. Protein translated in a non-reducing lysate in the presence of microsomes and then electrophoresed under non-reducing conditions had a greater mobility than the reduced product. This is due to the formation of a more compact structure with a lower hydrodynamic volume (Goldenberg \& Creighton, 1984). By varying the translation and analysis conditions it could be shown that both non-reducing translation conditions and the presence of microsomes were necessary for co-translational disulphide bond formation. Once the signal peptide has been removed, the pro-segment of the protein becomes competent for the folding reaction (Scheele \& Jacoby, 1982). This result conforms with the idea that the pro-sequence is essential for folding (Ahmad \& McPhie, 1979; Privalov et al., 1981). It has previously been shown that denaturation of chymosin is irreversible, whereas prochymosin can be renatured from the unfolded state (Sugrue et al., 1988).

Post-translational proteolysis was used to confirm that translocation had occurred and that the product corresponding to prochymosin was protected by microsomal membranes. However, when the membranes were solubilized with detergent, proteinase $\mathrm{K}$ was only able to digest the prochymosin partially, and a fragment of around $38000-M_{r}$ remained proteinaseresistant. This effect was only observed when a non-reducing lysate was used for translation: when a DTT-supplemented lysate was used, no protected fragment was observed. Therefore in a non-reducing lysate the translocated material not only forms disulphide bonds but also folds to a conformation which is resistant both to proteinase $\mathrm{K}$ and a combination of chymotrypsin and trypsin. This result highlights the importance of using an 'in vitro' translation system lacking thiol reductants that is conducive to the correct folding and disulphide bonding of proteins. The fact that authentic prochymosin and a highly similar aspartic proteinase, pepsinogen, also produce a proteinase $\mathrm{K}$-resistant fragment under similar conditions strongly suggests that the product synthesized in vitro is correctly folded. It is possible that this fragment is pseudochymosin, since its $M_{\mathrm{r}}$ corresponds to around 38000 .

We have also shown that the 'in vitro' product prochymosin can be activated at $\mathrm{pH} 2.0$ to a product corresponding in $M_{\mathrm{r}}$ to pseudochymosin. Furthermore, intermolecular activation of prochymosin to pseudochymosin in the presence of unlabelled chymosin contributes to the increased levels of pseudochymosin present. However, treatment at $\mathrm{pH} 4.7 \mathrm{did}$ not lead to activation, in contrast with the findings of Pedersen et al. (1979) with native prochymosin. In view of the complexity of the acid activation process, the low concentration of prochymosin and the high levels of other components in the translation mixes, and the contrast between these conditions and those for activation of purified prochymosin, it would be facile to offer an explanation for this discrepancy without further work.

The results indicate overall that translation in vitro in appropriate conditions can lead to the formation of prochymosin which is correctly folded by several criteria. These experiments form the basis for assessing the role of specific mutations within the pro-sequence which may be involved in the folding of prochymosin and in the process of activation to generate chymosin. Such a study will be important in revealing the relationship between sequence and structure and stability in the tertiary structure of prochymosin.

We are grateful to Dr. M. F. Tuite for his advice, to Dr. N. J. Bulleid for his helpful suggestions and to Dr. S. Angal for her interest. We are also grateful to Dr. B. M. Austen for his help in the preparation of dog pancreas microsomal membranes. This work was supported by grant GR/E/43966 from the Science and Engineering Research Council.

\section{REFERENCES}

Ahmad, F. \& McPhie, P. (1979) Can. J. Biochem. 57, 1090-1092 Austen, B. M., Kaderbhai, M. A., Hermon-Taylor, J. \& Ridd, D. H. (1984) Biochem. J. 224, 317-325

Bulleid, N. J. \& Freedman, R. B. (1988a) Biochem. J. 254, 805-810

Bulleid, N. J. \& Freedman, R. B. (1988b) Nature (London) 335, 649-651

Bulleid, N. J., Sheikh, A. \& Freedman, R. B. (1989) Biochem. Soc. Trans. 17, 1078-1079

Dottavio-Martin, D. \& Ravel, J. M. (1978) Anal. Biochem. 87, 562-565 Emtage, J. S., Angal, S., Doel, M. T., Harris, T. J. R., Jenkins, B., Lilley,

G. \& Lowe, P. A. (1983) Proc. Natl. Acad. Sci. U.S.A. 80, 3671-3675 Foltmann, B. (1970) Methods Enzymol. 19, 421-436

Foltmann, B. (1981) Essays Biochem. 17, 52-84 
Foltmann, B. \& Pedersen, V. B. (1977) Adv. Exp. Med. Biol. 95, 3-22 Foltmann, B., Pedersen, V. B., Jacobsen, H., Kauffman, S. \& Wybrant, G. (1977) Proc. Natl. Acad. Sci. U.S.A. 74, 2321-2324

Goldenberg, D. P. \& Creighton, T. E. (1984) Anal. Biochem. 138, 1-18

Harris, T. J. R., Lowe, P. A., Eaton, M. A. W., Millican, T. A., Patel, T. P., Bose, C. C., Carey, N. H.\& Doel, M. T. (1982) Nucleic Acids Res. 10, $2177-2187$

Jaenicke, R. (1987) Prog. Biophys. Mol. Biol. 49, 117-237

Jenkins, J. A., Tickle, I. J., Sewell, T., Ungaretti, L., Wollmer, A. \& Blundell, T. L. (1977) Adv. Exp. Med. Biol. 95, 43-60

Kaderbhai, M. A. \& Austen, B. M. (1985) Eur. J. Biochem. 153, 167-178

Kawaguchi, Y Shimizu, N., Nishimori, K., Uozumi, T. \& Beppu, T. (1984) J. Biotechnol. 1, 307-315

Krieg, P. A. \& Melton, D. A. (1984) Nucleic Acids Res. 12, 7057-7070 Laemmi, U. K. (F970) Nature (London) 227, 680-685

Maniatis, T., Fritsch, E.F. \& Sambrook, J. (1982) Molecular Cloning: A Laboratory Manual, Cold Spring Harbour Laboratory, Cold Spring Harbour, NY

Received 19 June 1990/15 August 1990; accepted 20 August 1990
Marston, F. A. O., Lowe, P. A., Doel, M. T., Schoemaker, J. M., White, S. \& Angal, S. (1984) Biotechnology 2, 800-804

Mellor, J., Dobson, M. J., Roberts, N. A., Tuite, M. F., Emtage, J. S., White, S., Lowe, P. A., Patel, T., Kingsman, A. J. \& Kingsman, S. M. (1983) Gene 24, 1-14

Moir, D., Mao, J., Schumm, J. W., Vovis, G. F., Alford, B. L. \& Taunton-Rigby, A. (1982) Gene 19, 172-138

Nishimori, K., Kawaguchi, Y., Hidaka, M., Uozumi, T. \& Beppu, T. (1982) Gene 19, 337-344

Pedersen, V. B. \& Foltmann, B. (1975) Eur. J. Biochem. 55, 95-103

Pedersen, V. B., Christensen, K. A. \& Foltmann, B. (1979) Eur. J. Biochem. 94, 573-580

Pelham, H. R. B. \& Jackson, R. J. (1976) Eur. J. Biochem. 67, 247-256

Privalov, P. L., Mateo, P. L., Khechinashvili, N. N., Stepanov, V. M. \& Revina, L. P. (1981) J. Mol. Biol. 152, 445-464

Scheele, G. \& Jacoby, R. (1982) J. Biol. Chem. 257, 12277-12282

Sugrue, R., Freedman, R. B., Lowe, P. A. \& Marston, F. A. O. (1988) Biochem. Soc. Trans. 16, 59-60 